\title{
Стихи и письма Якова Емельянова как источник для изучения языковой нормы татар-кряшен XIX века
}

\begin{abstract}
Нуриева Фануза Шакуровна, Казанский (Приволжский) федеральный университет; Институт языкознания РАН; Институт системного программирования Российской академии наук (Москва); fanuzanurieva@yandex.ru Фахретдинова Гульназ Нурхаметовна, Казанский национальный исследовательский технологический университет; gulnazkhamidull@mail.ru
\end{abstract}

В статье проводится анализ языковых особенностей сборника стихотворений «Стихи на крещено-татарском языке» Якова Емельянова, изданного в 1879 году для крещеных татар. Письменные памятники являются одним из основных источников изучения истории языка, однако этот сборник еще не подвергался изучению. В статье описываются фонетические, морфологические и лексические особенности текста памятника в сопоставлении с языковым материалом богослужебных переводных кириллических книг, а также с данными татарского литературного языка и его современных диалектов. В результате анализа нам удалось выявить ряд графико-фонетических особенностей, среди которых оглубление гласных, употребление дифтонгов и определенных гласных и согласных в соответствии с литературными вариантами, выпадение гласных. К морфологическим особенностям относятся аффикс -blм, -ем вместо литературного первого лица единственного числа будущего времени на - , аффикс инфинитива -мага вместо литературного -рга, а также лексические единицы, которые отличают язык памятника от современного татарского литературного языка и некоторых его диалектов. При этом все они зафиксированы в мамадышском и лаишевском говорах среднего диалекта татарского языка, в регионе, где родился и жил поэт. Таким образом, мы можем предположить, что в стихах Якова Емельянова представлены реальные разговорные варианты слов того времени, а в переводных богослужебных книгах эти особенности были нивелированы. Анализ «Стихов...» позволяет уточнить историю татарского языка и его диалектов.

Ключевые слова: Яков Емельянов, татарский язык, крещеные татары, XIX век, стихи, заказанский говор

\section{USING YAKOV EMELYANOV'S POEMS AND LETTERS AS A LANGUAGE NORM FOR 19th CENTURY KRYASHEN TATARS}

Fanuza Sh. Nurieva, Kazan (Volga region) Federal University; Institute of Linguistic RAS, the Russian Academy of Science, Ivannikov Institute for System Programming of the RAS; fanuzanurieva@yandex.ru Gulnaz N. Fakhretdinova, Kazan National Research Technological University; gulnaz_khamidull@mail.ru

The article analyzes the language features of Yakov Emelyanov's collection of "Poems in the Christianized-Tatar language", published in 1879 for Baptized Tatars. Written manuscripts are one of the main sources for studying the history of the language, however, this collection has not yet been considered. The article analyzes the phonetic, morphological, and lexical features in the text. The language of the poems is compared with the linguistic material of the translated liturgical Cyrillic books, the Tatar literary language and its modern dialects. The results suggest that there are a number of graphic and phonetic features, including rounded vowels, the use of diphthongs and certain vowels and consonants in accordance with the literary variants, and the vowel deletion. The morphological features include the affix $-y m$, -em instead of the literary first person singular of the future tense with - $r$, the infinitive -maga affix instead of the literary - rga, as well as lexical peculiarities that distinguish the poems language from the modern Tatar literary language and some of its dialects. Moreover, all of them are recorded in the Mamadysh and Laishev dialects of the Tatar language, the regions where the poet was born and lived. Thus, we can assume that forms of real colloquial words of that time are presented in Yakov Yemelyanov's poems, and in translated liturgical books, these features were leveled. Analysis of the poems allows observing the history of the Tatar language and its dialects.

Keywords: Yakov Emelyanov, Tatar language, Christianized Tatars, $19^{\text {th }}$ century, poems, Zakazan subdialects

Работа над статьей велась в рамках проекта РНФ № 18-18-00501 «Создание электронного диалектологического атласа тюркских языков России». Авторы благодарны анонимным рецензентам статьи и Ю. В. Норманской за ценные замечания и консультации в ходе работы. 
Распространение православной религии в Поволжье привело к образованию довольно многочисленной группы крещеных татар (кряшен). Исследователи выделяют две локальные подгруппы: «старокрещеные», предки которых приняли православие в основном в XVI-XVII вв., и «новокрещеные», крестившиеся после проведения первой государственной ревизии в 1722 г. [Исхаков 2015: 72].

Исследование исторического прошлого кряшен Волго-Уральского региона тесно связано с развитием исторической науки в России в эпоху Петра I. Открытие в 1724 году Петербургской академии наук дало определенный толчок изучению истории и этнографии народов Поволжья и Сибири. В 1733 году, по дороге в Сибирь, немецкие исследователи Г. Миллер и И. Гмелин, побывав в Среднем Поволжье, собрали сведения об особенностях культурной жизни и быта народов Поволжья и Урала. Находясь в Казани в 1733 году, они освещали учебную и просветительскую деятельность кряшенских школ, писали об этническом составе учащихся [Миллер 1791].

Во время правления Екатерины II повышается внимание к истории и культуре народов Восточной России, дается старт научным экспедициям в Поволжье и Сибирь. В 1762 году выходят в свет труды историка и географа П. И. Рычкова по материалам экспедиции в Оренбургскую губернию, в которых впервые дается историко-этнографическое описание кряшен [Рычков 1762]. Данная работа также имеет особое значение для изучения истории нагайбаков. Сведения о кряшенах, проживающих в Оренбургской области, нашли отражение и в работе П. И. Рычкова «История Оренбургская...» [Рычков 1896].

Дальнейшее исследование исторического прошлого кряшен неразрывно связано с анализом деятельности крупных научных казанских центров, способствующих развитию исторических и этнографических школ. В результате открытия в 1800 году класса татарского языка в Казанской духовной академии, а в 1807 году - восточного отделения в Казанском императорском университете, Казань становится центром востоковедения России, где работают известные специалисты, занимающиеся изучением языка, истории и культуры местных народов. В 1854 г. Казанская духовная академия открывает миссионерское отделение, цель которого - подготовить миссионеров - знатоков восточных языков. Наиболее известными учениками этого отделения были Н. И. Ильминский, А. А. Бобровников, Е. А. Малов, М. А. Машанов, Н. П. Остроумов и др.

В это время публикуется целый ряд трудов, посвященных политике христианизации. Казанский университет выпустил двухтомный труд адъюнкт-историка М. С. Рыбушкина «Краткая история города Казани», в котором освещается миссионерское движение церкви и религиозная деятельность жителей этого региона [Рыбушкин 1849]. В работе «Казанская история» Н. Баженова описывается завоевание Казанского ханства и принятие христианства местными языческими или мусульманскими народами [Баженов 1847]. Историк С. В. Ешевский, характеризуя миссионерскую деятельность церкви, указывает на сравнительно низкий уровень проникновения христианства в повседневную жизнь нерусских народов, в том числе кряшен, и признает неоднозначность политики христианизации [Ешевский 1900]. В последней трети XIX в. и в первой половине XX в. известным тюркологом и миссионером Е. Маловым были написаны первые работы, посвященные развитию миссионерской деятельности среди татар, где также отражается религиозное положение кряшен [Малов 1872].

29-томная «История России с древнейших времен» (1851-1879) профессора Московского университета С. М. Соловьева приводит детальную хронику политической истории России, где, наряду со многими другими историческими фактами, описываются методы христианизации инородцев в XVI-XVIII веках, создается общая картина формирования кряшенских групп [Соловьев 1851-1879]. В работе историка Г. И. Перетятковича основное внимание уделяется положению нерусских народов в Московском государстве, отмечается роль православной церкви в завоевании Казанского ханства и продвижении государственной идеологии [Перетяткович 1882].

В 1867 г. при Казанском Благовещенском кафедральном соборе было создано «Братство святителя Гурия», основной целью деятельности которого были подготовка учителей-миссионеров и оказание миссионерской учебно-методической и издательской помощи [Исхаков 2015: 72]. В эту пору широкое распространение получила новая концепция христианского просвещения, которая включала в себя развитие начальных конфессиональных школ для нерусских народов края. Основоположником данной концепции стал профессор Казанской духовной академии и Казанского университета, востоковед, членкорреспондент Академии наук Николай Иванович Ильминский. С целью популяризации и расширения религиозного просвещения среди кряшен в 1860-70-х годах Н. И. Ильминским и его сторонниками были затронуты различные аспекты религиозно-просветительской деятельности: развитие Казанской центральной кряшенской школы и ее районных отделений, перевод православных книг на татарский язык с использованием кириллицы [Нуриева 2017: 167-169]. Н. И. Ильминский считал: «Образование инородческим детям должно преподаваться в таком виде, чтобы и ими легче оно усваивалось. А для этого самое лучшее средство — образовательные книги изложить на собственном языке инородцев» [Николь- 
ский 1905: 4]. В основу букваря (1862 г.), составленного Н И. Ильминским, «...для обучения детей кряшен был заложен народный татарский язык, каким говорят старокрещеные татары Мамадышского уезда Казанской губернии, среди и при помощи которых я переводил букварь» [Ильминский 1892: 6]. На этом поприще его правой рукой становится крещёный татарин, послушник Казанского Иоанновского монастыря В. Т. Тимофеев, выходец из крестьян деревни Никифорово Мамадышского уезда Казанской губернии. Таким образом, заказанский говор составил языковую норму в переводных текстах и при обучении и составлении учебных пособий в специализированных учебных заведениях для крещеных татар. Открытие миссионерских школ и просветительская деятельность под руководством и при главном участии Н. И. Ильминского дали свои результаты: сети кряшенских школ, переводы богослужебных текстов на основе кириллицы способствовали более эффективному применению татарского языка в церковной практике. Все богослужебные и учебные книги написаны практически в единой орфографической традиции (ср. подробнее [Норманская, Нуриева 2018], где показано, что только в мишарских кряшенских книгах использованы иные орфографические нормы).

Интересно, что венгерский исследователь тюркских и монгольских народов Габор Балинт, который собирал материалы по кряшенскому языку в 1871-1874 гг. в Казани на базе школы, созданной Н. И. Ильминским, с помощью татар В. Т. Тимофеева и Симона Гяурле, иначе зафиксировал в своих записях особенности мамадышского диалекта, см. подробнее [Wolgatatarische Dialektstudien 1988: 6]. Венгерский исследователь собрал фольклорные тексты (сказки, поговорки, пословицы, песни), составил словарь (около 4 тысяч лексических единиц). В своих исследованиях при транскрипции он использовал латинскую графику. Представляется интересным возможное в будущем полное изучение языковых особенностей, отраженных в материалах Г. Балинта. Но, как отмечает А. Берта, издатель текстов и словаря Г. Балинта, в этих рукописях есть особенности, которые трудно объяснить на основании наших знаний о современных кряшенских диалектах и первых кириллических книгах. В частности, во всех кряшенских источниках, начиная со словаря Остроумова, в начале слов представлено ж- в соответствии с й- современного татарского литературного языка. В материалах Г. Балинта $\breve{j}$ в начале слов представлено в арабо-персидских заимствованиях и небольшом количестве исконно тюркской лексики, например, в словах jät 'быстро', jŏr 'приносящий удовольствие'. В подавляющем большинстве тюркских слов, которые в первых кириллических книгах имеют ж-, в анлауте представлен $j$-, соответствующий татарскому литературному языку. Сам Г. Балинт в своей грамматике это комментирует и указывает, что в реальном произношении наблюдаются постоянные колебания - и - в исконно тюркских словах, поэтому он принял решение давать унифицированную запись через $j$ - (ср. [Wolgatatarische Dialektstudien 1988: 11-12]). Это заставляет предположить, что и авторы кириллических книг под руководством Н. И. Ильминского производили орфографическую нормализацию, но в сторону ж-.

В связи с этим представляется интересным обратиться к анализу языковых особенностей в собственных произведениях кряшен. Среди книг, написанных кряшенами на татарском языке, особый интерес представляет сборник стихотворений Якова Емельянова (1848-1893), творчество которого составляет своеобразную страницу татарской поэзии. Первый поэт из кряшен, он оценивает важные вопросы татарской общественно-культурной жизни XIX века с точки зрения представителя христианского духовенства. Д. Ф. Загидуллина отмечает, что Я. Емельянов стал одним из первых татарских поэтов, обратившихся к романтическим мотивам народности и народного фольклора, вновь громко зазвучавшим в татарской литературе в начале XX века в стихотворениях Г. Тукая, С. Рамиева, Н. Думави [Загидуллина 2013: 768]. Творчество Я. Емельянова вызывало интерес как у современников, так и у последующих исследователей. Сведения о Я. Емельянове были приведены в 1896 году в журнале «Православный собор» в письмах Николая Ильминского, адресованных кряшенам. Творчество поэта стало объектом изучения в трудах Г. Тулумбаева，А. Григорьева，Х. Гусмана， М. Гайнуллина， М. Глухова， Р. Ахмета， Х. Миннегулова, Р. Файзуллина, И. Халикова, Р. Исхакова и других ученых-литературоведов.

Для того чтобы проанализировать языковые особенности его произведений, полезно проследить жизненный путь первого кряшенского поэта. Родился Яков Емельянович Емельянов в 1848 году в деревне Алан-Полян Лаишевского уезда Казанской губернии (ныне Рыбно-Слободский район Республики Татарстан), в семье государственных крестьян Емельяна Петровича и Акулины Сергеевны. Яков вырос в обычной крестьянской многодетной семье, которая не отличалась особой религиозностью и образованностью. Незадолго до открытия в 1864 г. центральной крещено-татарской школы 16-летним юношей Яков прибывает в Казань. Основная деятельность школы была связана с подготовкой учителей грамоты для сельских школ, хотя и отмечается православно-просветительский характер данного заведения. Узнав об открытии школы, Я. Емельянов поступает туда учиться и становится одним из первых воспитанников заведующего школой В. Т. Тимофеева, под влиянием стихотворческой деятельности которого юноша начал проявлять интерес к поэзии. Здесь будущий поэт изучает азбуку, начальную математику, геогра- 
фию, Закон Божий и хоровое пение православных молитв. Обучение проходило на родном языке, ученики также знакомились с основами грамматики русского языка, читали Евангелие и жития святых, устно переводя их на родной язык. Обучение и воспитательный процесс в школе способствовали воспитанию в учениках православной культуры, приобретению христианского мировоззрения и усвоению христианских понятий. Яков Емельянов был одним из первых выпускников крещено-татарской школы, в 1867 г. он получил назначение учителем братской школы села Уреево-Челны Лаишевского уезда, где проработал 6 лет. Емельянов интересовался русской литературой, в частности творчеством Н. Некрасова, И. Никитина, читал богослужебные книги, переведенные на татарский язык. Последующие годы Я. Емельянов краткосрочно работал в нескольких крещено-татарских школах. Одновременно с успешной учительской деятельностью поэт был посвящен в сан священнослужителя: сначала дьякона (1874 г.), а затем священника (1880 г.) - и был назначен настоятелем православного прихода в с. Чура Мамадышского уезда, сочетая церковное служение с работой законоучителя Чуринской земской школы и плодотворно осуществляя миссионерскую деятельность. Однако из-за конфликтов с богатыми прихожанами Я. Емельянов в 1888 г. был переведен в с. Урясь-Учи Мамадышского уезда (ныне с. Танькино Кукморского района). Он умер 3 февраля 1893 г. в возрасте 45 лет.

Сохранились письма Емельянова его наставникам В. Т. Тимофееву и Н. И. Ильминскому, в которых сообщается о разных проблемах, связанных с обустройством школы, налаживанием отношений с местными жителями, церковной деятельностью.
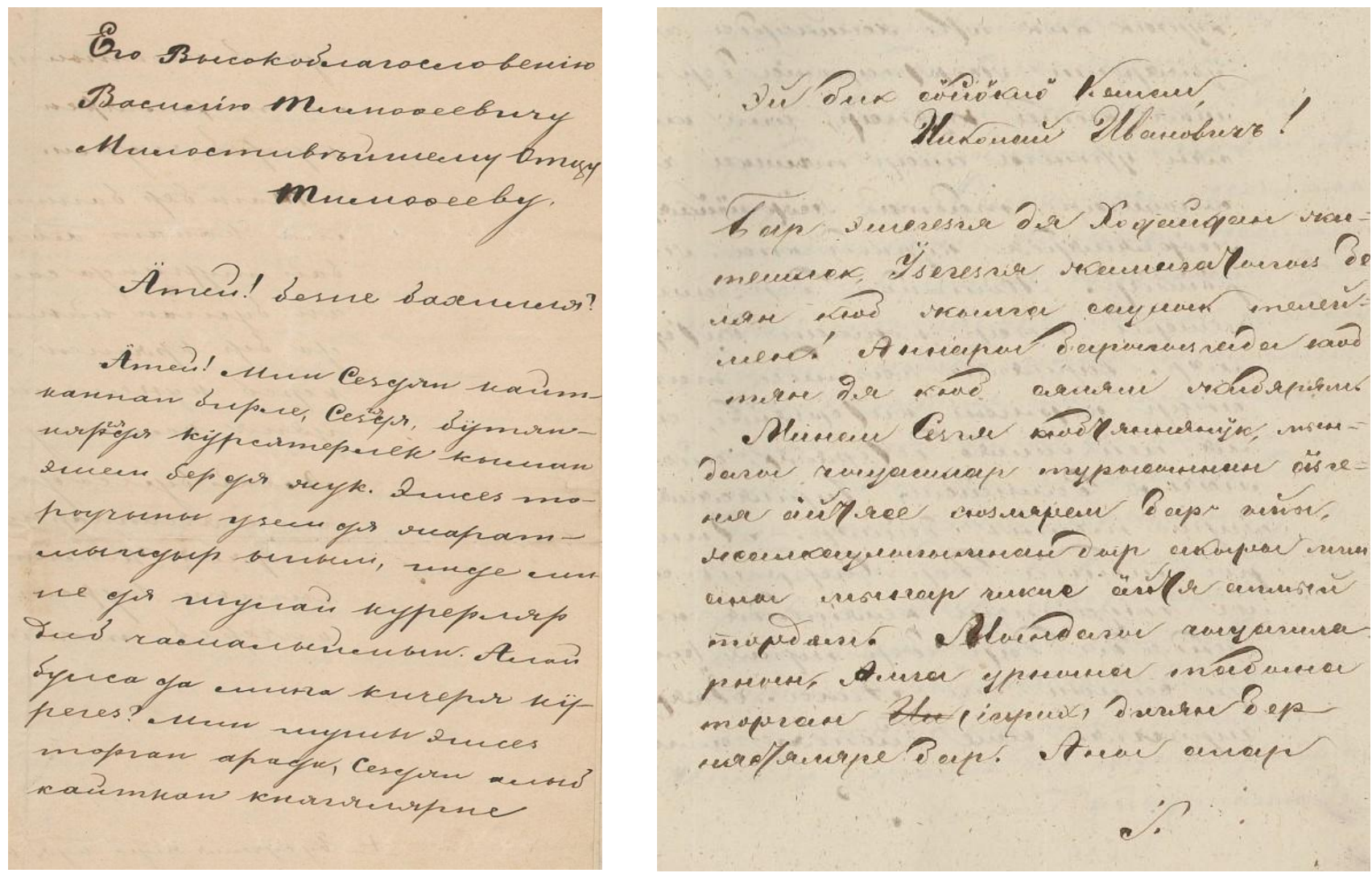

Илл. 1. Письма Я. Емельянова своим наставникам В. Тимофееву и Н. Ильминскому

В 1870-е гг. он впервые пробует себя на литературном поприще. В 1879 г. с одобрения и при поддержке Совета Братства св. Гурия выходит первый сборник Емельянова под названием «Стихи на крещено-татарском языке» (известный как «Даржа аби кнегесе» 'Книга бабушки Дарьи'), состоящий из 11 стихотворений, различающихся по стилю и жанровому содержанию. Хотя при жизни поэта было опубликовано только два небольших поэтических сборника, но, благодаря бытовому просторечию, естественному непринужденному характеру стихов и народно-разговорным формам, произведения Емельянова стали уникальным языковым памятником того периода. Тексты стихотворений представляют интерес для сравнения с современным разговорным языком говоров Заказанья среднего диалекта, они играют важную роль при определении хронологии языковых явлений. 
Исследуемый материал в настоящее время представлен в виде конкорданса на портале ЛингвоДок (http://ingvodoc.ispras.ru/dictionary/3913/1/perspective/3913/2/view) и содержит более 2 тысяч словоформ. В текстах стихов и писем диалектная лексика ${ }^{1}$ в процентном отношении малочисленна - всего 90 слов.

Прежде чем описать фонетические и морфологические изоглоссы, представленные в текстах стихов и писем Я. Емельянова, остановимся на особенностях графики.

В современной татарской письменности употребляются 33 буквы русского алфавита с добавлением к нему особых знаков для специфических фонем: $ә, \theta, y, \nsim, \mu, ~ h$.

В основу переводов комиссии при «Братстве святителя Гурия», которая создала орфографию на основе кириллицы, был также положен русский алфавит:

\begin{tabular}{|c|c|c|c|c|}
\hline $\mathrm{A} \mathrm{a}$ & Ж ж & $\mathrm{M} \mathrm{M}_{\mathrm{M}}$ & $\mathrm{Pp}$ & Ч ч \\
\hline Ä ä & 33 & $\mathrm{H} \mathrm{H}_{\mathrm{H}}$ & $\mathrm{Cc}$ & \\
\hline Б б & И и & $\mathrm{H}$ & $\mathrm{T}_{\mathrm{T}}$ & \\
\hline$\Gamma_{\Gamma}$ & Й й & $\mathrm{Oo}$ & $\mathrm{y} y$ & \\
\hline Д д & К к & Ö ӧ & $\ddot{\mathrm{y}} \ddot{\mathrm{y}}$ & \\
\hline $\mathrm{E} \mathrm{e}$ & Л л & П п & $\mathrm{XX}$ & \\
\hline
\end{tabular}

Для специфических звуков татарского языка были включены дополнительные буквы: $\ddot{a}, \ddot{o}, \ddot{y}$. Однако в изданиях не всегда прослеживается последовательность в выборе букв для переднерядных гласных. Как отмечает сам Н. И. Ильминский, «при своем консерватизме я в окончательно установившейся орфографии употреблял русские мягкие $я$ и $ю$, где можно, то есть после согласных, а в начале слов должен был писать $\ddot{a}$ и $\ddot{y}$; точно так же вместо $e$ писал в начале слов э. Таким образом, в наш крещено-татарский алфавит вошли буквы с различительным двоеточием: $\ddot{a}, \ddot{o}, \ddot{y}$. Буквы $2, \kappa, \varkappa$ в текстах передавали не только заднеязычные [2], [к] и переднеязычный щелевой [ж], но и глубокозаднеязычные [₹], [k] и переднеязычный щелевой $[\%]$. Для обозначения носового $[H]$ употреблялось слияние $\mu$ и г. Принципы письма были просты - писать так, как слышится» [Ильминский 1892: 7]. Анализ текстов стихов и писем Я. Емельянова показал, что он использовал именно этот алфавит.

Однако, несмотря на то что Яков Емельянов был выпускником кряшено-татарской школы и при записи своих произведений употреблял графику, разработанную Н. И. Ильминским, в его стихах присутствует ряд графических особенностей, не встреченных нами в учебной или богослужебной литературе (см. подробнее ниже). В настоящей статье поставлена задача описать все отличия языка стихов Якова Емельянова от литературного татарского языка и первых кириллических богослужебных и учебных книг и на основании сравнения с современными диалектами установить природу этих отличий. С учетом биографических сведениий о местах рождения и работы Якова Емельянова, сравнение особенностей его текстов проводится в первую очередь с лаишевским и мамадышским говорами.

\section{Фонетические особенности ${ }^{2}$}

\section{Губная гармония}

В анализируемом сборнике (здесь и далее мы обозначаем его как [C] с указанием страницы) в случае наличия гласных $o, \ddot{o}$ в корне наблюдается последовательное огубление гласных среднего подъема $b l, e$ второго слога. По статистике конкорданса http://ingvodoc.ispras.ru/dictionary/3913/1/perspective/3913/2/view:

1) после $o$ первого слога огубление $b$ произошло в 25 случаях, ср. тормош - литер. тормыш 'жизнь', бозок - литер. бозык 'испорченный', и НЕ произошло в 2 случаях: соныннан - литер. соңьыннан 'позже'; коры - литер. коры 'сухой'.

2) после $\ddot{о}$ первого слога огубление $e$ произошло в 49 случаях, ср. ӧчӧн - литер. өчен 'за'; тӧбӧ литер. төбе 'дно', кӧнӧндё - литер. көнендә 'в день', и НЕ произошло в 2 случаях: тӧшемдӓ - литер. төшемдә 'в моем сне'; кӧтеб тордом - литер. көтеп тордым 'ждала' .

Как видим из приведенных примеров, характер слога (открытость - закрытость: коры vs. тӧбӧ, бозок vs. кӧтеб) и консонантное окружение не могут быть учтены как факторы, влияющие на отсутствие губной гармонии.

В частности, губная гармония отмечена в следующих грамматических формах:

1. В личных аффиксах презенса и повелительного наклонения: 2 л. ед. ч.: сӧйлӧй-сӧн - литер. сөйлисең 'расказываешь' [С: 20], кӧймӧй-сӧн — литер. көймисең 'не заботишься' [С: 21], 3 л.: тӧкӧр-сӧн -

\footnotetext{
${ }^{1}$ Под диалектной лексикой понимаются слова, не входящие в литературный язык и имеющие ограниченное территориальное распространение.

${ }^{2}$ Рассматриваются примеры особых рефлексаций, которые зафиксированы в 3 или более встречаемостях.
} 
литер. төкер-сен 'пусть плюют' [C: 22 bis]; 2 л. мн. ч.: тот-огоз - литер. тот-ыльыз 'примите' [C: 2], от-огоз - литер. от-ыльыз 'запомните' [C: 2, 2], кӧтӧб тор-огоз - литер. көтеп тор-ыгыз 'ждите' [С: 27].

2. В показателе прошедшего категорического -ДЬІ: a) кӧйон-дӧ-к - литер. көен-де-к '(мы) опечалились' [С: 13], кӧтӧб тор-до-к — литер. көтеп тор-ды-к '(мы) ждали’ [С: 30], б) китереб ор-до-м - литер. китереп ор-дыл-м ' (я) ударила' [С: 30], тор-до - литер. тор-ды 'встала' [С: 36], тӧш-тӧ - литер. төш-те 'опустилась' [С: 31], жӧгӧрӧб жӧр-дё- литер. йөгереп йөр-де ‘бегал' [С: 36].

3. В аффиксе причастия будущего времени на -ыр: сӧйӧн-ӧр - литер. сөен-ер 'будет радоваться' [C: 4, 20, 35], кӧйӧн-ӧр - литер. көен-ер 'будет страдать' [С: 4, 20, 34]; в частности, в инфинитиве: котол-ор-га - литер. котыл-ыр -га 'избавиться' [С: 9].

4. В аффиксе деепричастия -ыn: аякка тор-об - литер. аякта бас-ылn 'стоя' [C: 13], кор-об — литер. кор-ылп 'воздвигая' [С: 9], сӧйӧн-ӧб - литер. сөен-еп 'с радостью', тӧш-ӧб калган — литер. төш-еп калган 'упали' [С: 14], кӧл-ӧб — литер. көл-еп 'смеясь' [С: 22], борчол-об — литер. борчыл-ыли 'беспокоясь' [C: 30].

5. В аффиксах принадлежности: орчог-ом - литер. орчыс-ылм 'мое веретено' [С: 28], тӧш-ӧм-нӧ литер. төш-ем-не 'мой сон-Асс' [C: 35], ӧи-ӧбӧз-гё — литер. ө-ебез-гә 'наш дом-DАТ' [C: 26], жорт-он- $а-$

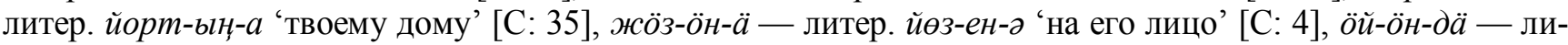
тер. ө-ен-дә 'в (его) доме' [С: 6], тӧб-ё — литер. төб-е 'дно (его)' [С: 17], тӧн-ӧ блӓн - литер. төн-е белән '(той) ночью' [С: 18], кол-о - литер. кол-bl 'раб (его)' [С: 34], олоны - литер. ольныbl 'взрослого' [C: 4], тормошон - литер. тормышын 'твою жизнь' [С: 6].

Как показано в статье [Норманская, Нуриева 2018: 102-104], по степени проявления губного сингармонизма ранее проанализированные татарские кириллические памятники можно разделить на три группы:

1) огубление гласных $[b t],[e]$ второго слога происходит всегда, если в первом слоге есть $[o],[\theta]$ : [Словарь 1880; Земная жизнь 1900];

$2)$ огубление гласных $[b l],[e]$ происходит в подавляющем большинстве случаев, если в первом слоге есть $[o],[\theta]:$ [Словарь 1876; Требник 1881];

$3)$ огубление гласных $[b l],[e]$ происходит достаточно редко, если в первом слоге есть $[o],[\theta]$ : [Евангелие 1866, 1908].

Стихи Якова Емельянова наиболее близки книгам второго типа: [Словарь 1876; Требник 1881], в которых огубление происходит в подавляющем большинстве случаев.

В говорах современных кряшен также при $o, \theta$ первого слога происходит огубление $b l, e$ последующих слогов. Эта особенность системно сохранилась в заказанском говоре кряшен, в дрожжановском, чистопольском говоре мишарского диалекта [Баязитова 1986: 54], ср. карту этого явления в современных диалектах $\mathrm{http}: / /$ atlas.antat.ru/atlas/maps.html?mapnom=7\#.
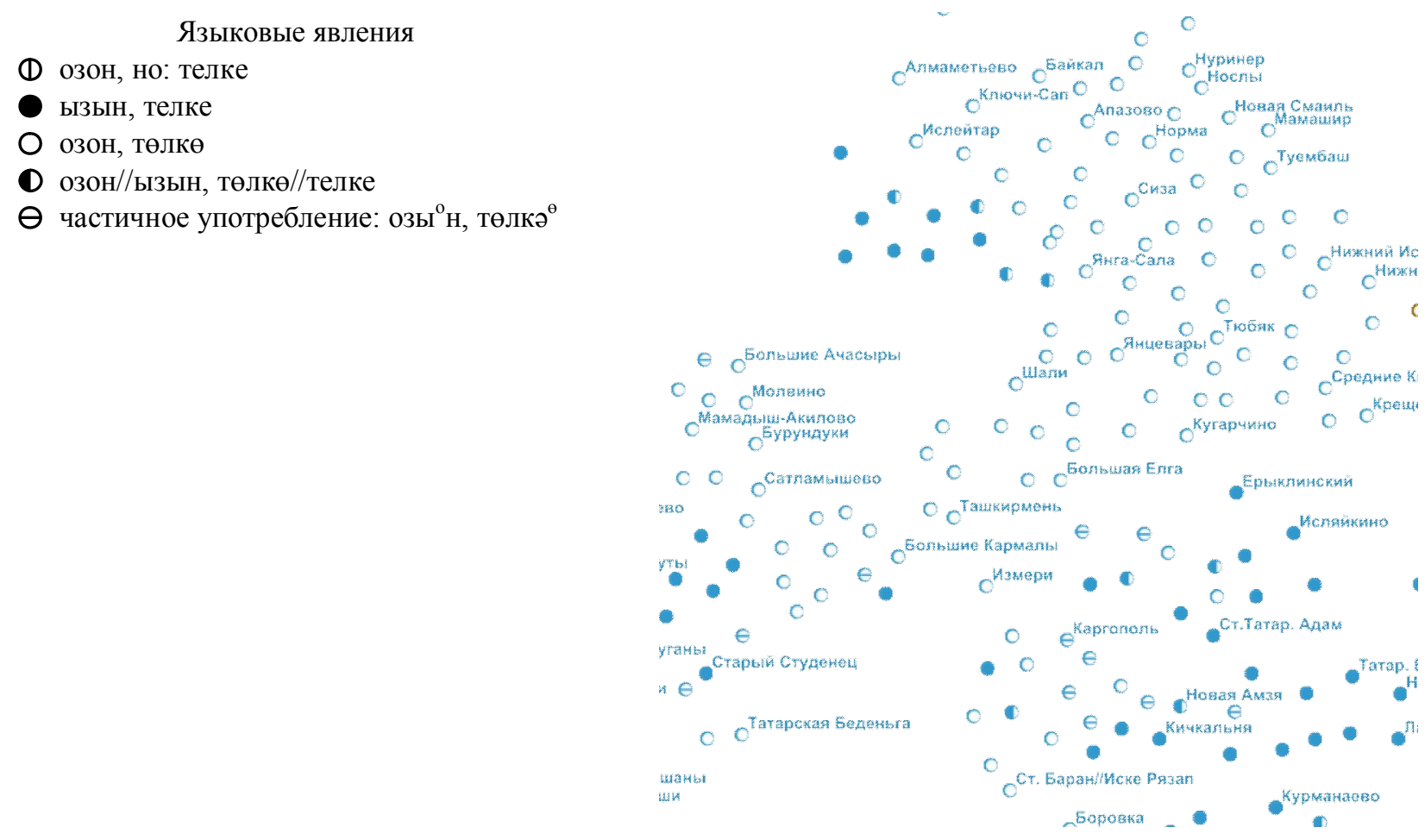


\section{Употребление дифтонгов}

В татарском языке истинных дифтонгов нет, имеются только «ложные» нисходящие и восходящие дифтонги, которые имеют в своем составе один полноценный гласный и второй полугласный звук. В сборнике Якова Емельянова [С] зафиксированы последовательности типа -ыу, -ей, -оу, -ей, -ӧй.

Сам Н. И. Ильминский специально оговаривает специфику употребления дифтонгов: «Кроме приспособления русских букв к татарским звукам мне пришлось постепенно изменять и устанавливать орфографию. В первом издании букваря я писал су 'вода', аул 'деревня', аю 'медведь'. Теперь пишем cbly, ayblл, aйbly. Это сочетание -bly род двугласной, внушено мне крещено-татарскими мальчиками, учениками Казанской школы, которые по чутью употребляли его в своих письмах, но оно совпадает с нормальным составом слов в основном тюркском языке» [Ильминский 1892: 8]. Примеры:

a) bly - литер. $y$ : кыуаныр - литер. куаныр 'обрадуется' [С: 7, 11], cыууы - литер. суы 'его вода' [C: 31], сынальууны - литер. сыналуны 'испытание' (вин. падеж) [С: 6], ыуулаб - литер. улап 'зазывая' [C: 8], кыуаныб - литер. куанып 'радуясь' [С: 10], жыуаныр - литер. юаныр 'утешится' [С: 11], жыуансын - литер. юансын 'пускай утешается' [C: 11], жыуата - литер. юата 'утешать' [С: 13], калдырыудан - литер. калдырудан 'оставивший' [С: 15], жыуганчук - литер. юганчы ук 'прежде чем помоет' [C: 16], кыусалар да - литер. кусалар да 'если будут гнать' [С: 18], уятыу - литер. уяту 'пробуждение' [C: 20], арыумы - литер. арумы 'как здоровье' [С: 27], арыу — литер. ару 'хороший' [С: 28], бульуу блӓн - литер. булу белән 'будет' [C: 32];

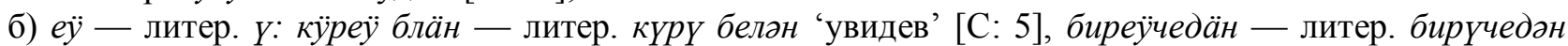
‘у дающего' [C: 14], эчё̈не - литер. эчүне ‘питье' [С: 17], килё̈дӓ - литер. килү дә ‘приход’ [С: 26], чӓй эчё - литер. чәй эчү 'чаепитие' [С: 31$]$;

в) оу — литер. $y$ : тойоучы — литер. тоючы 'ощущающий' [С: 6];

г) ей - литер. и: нейдӓндер - литер. нидәндер 'наверное, от чего' [С: 26], кейгәннӓр — литер. кигәннәр 'надели' [С: 19, 26, 29], деймӓ - литер. димә 'не говори' [С: 31], ӓбей - литер. әби 'бабушка' [C: 27], сейрӓк - литер. сирәк 'редки' [С: 31], килешмей - литер. килешми 'не подходят' [С: 31], бирешмей - литер. бирешми 'пренебрегают' [С: 31], эчейем - литер. эчим 'выпью' [C: 32], телеймен литер. телим 'желаю' [П], тирлейем - литер. тирлим 'потею' [С: 32], шишейем - литер. чишим 'расстегну' [С: 32], тирлей-тирлей - литер. тирли-тирли 'потея' [С: 32].

д) ӧи — литер. и: жӧрӧй - литер. йөри 'ходит' [C: 18].

По употреблению дифтонгов -bly, -ё̈, -ей наблюдаем идентичную картину в текстах переводных миссионерских богослужебных книг. Примеры: ышианыу — литер. ышану 'поверить' [Евангелие: 21], куркыу - литер. курку 'испуг' [Евангелие: 22], тыйыу - литер. тыю 'запрещать' [Евангелие: 22], ней - литер. ни 'что' [Евангелие: 22], бетмей - литер. бетми 'не заканчивается' [ЧДК: 29], кыуыб литер. куыл 'прогнав' [Евангелие: 22], ӓйтеу - литер. әйтү 'сказать' [ЧДК: 28], кыууат - литер. куәт 'сила, мощь' [ЧДК: 30] и др.

Аналогичное явление сохранилось в говорах современных крещеных татар. Кроме дифтонгов, которые имеются в татарском литературном языке, употребляются дифтонги -blw, -ew, -eй. Примеры: ней литер. ни 'что', бейем - литер. бием 'моя свекровь', үгей - литер. үги 'не родной', телей - литер. тели 'желает', эиләмей — литер. эшләми 'не работает', кейем - литер. кием 'одежда', тейеш - литер. тиеш 'должен'. Употребление дифтонга ей особенно характерно для говоров заказанских кряшен, т. е. мамадышских и лаишевских. В конце слогов и слов звукам литературного языка $y, Y$ в говорах заказанских кряшен соответствуют дифтонги -blw, -ew, например: укыw - литер. уку 'учеба', тылған - литер. туган 'родной, родственник', cыw - литер. cy 'вода', китеw - литер. китү 'уйти', ыьттырма -

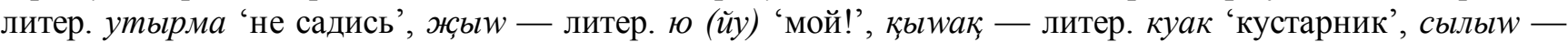
литер. сылу 'стройный, красивый’ [Баязитова 1986: 56].

Таким образом, употребление дифтонгов -bly, -eё, -ей в [C] соответствует богослужебным текстам и современным говорам заказанских кряшен, также оно представлено в диалектах пермских, сибирских, касимовских татар [Баязитова 1986: 56-57].

\section{$u$ в соответствии с литературным $e$ (э)}

В тексте сборника Емельянова [C] встречены написания $u$ вместо литературного $e$ (э): ирелӓрен литер. эреләрен 'крупные' [C: 13], инӓ - литер. энә 'иголка' [C: 21], гӱчтинӓченӓ - литер. күчтәнәчеңрә 'гостинцы' [С: 28]. Последнее слово - русское заимствование, для которого в памятнике наблюдается менее адаптированнная, чем в литературном татарском, форма, а первые два относятся, видимо, к случаю специфической рефлексации пракыпчакского сочетания *ij-, на который имеется карта № 15 в 
[http://atlas.antat.ru/atlas/maps.html?mapnom=15] АТНГ. См., например, [Дыбо 2013: 125] с реконструкцией *ijrig или *idrig для «крупный»; ср. также кыпчакские формы слова «игла» типа ijne: казах. ине /эjne/ 'игла' (ср. іні /эnэ/ 'младший брат'), кирг. ийне, алт. ийне.

Эта черта не зафиксирована нами в других кряшенско-татарских книгах, проанализированных нами ранее [Евангелие 1866; Словарь 1876; Словарь 1880; Требник 1881; ОП 1883; Учение 1897; Земная жизнь 1900; Евангелие 1908]. В мишарском памятнике есть внешне схожее явление, ср. примеры употребления графемы $u$ в соответствие с лит. $е$, э: Билдирирь [Священная история 1862: 1] - лит. тат. белдерер 'даст знать', устирирь [Священная история 1862: 9] - лит. тат. үстерер 'вырастит', битиргянь [Священная история 1862: 9] — лит. тат. бетергән 'уничтожил'. Эта особенность прослеживается во всей книге практически регулярно за исключением $e$ в однослогах, например, в эшь - лит. тат. эш 'работа' [Священная история 1862: 46], и в формах слова бер- 'один': бергя - лит. тат. бергә 'вместе' [Священная история 1862: 15], берси - лит. тат. берсе 'один из них' [Священная история 1862: 24]. В мишарском памятнике речь идет скорее о сохранении архаичного рефлекса ПТю *i (без эффектов волго-уральского «перелома гласных»).

По данным Атласа татарских народных говоров явление $i$-образного отражения пракыпчакского сочетания * $i j$ характерно для мамадышского, дубъязского, лаишевского говоров Заказанья http://atlas.antat.ru/atlas/maps.html?mapnom=15\#.

\begin{tabular}{l}
\multicolumn{1}{c}{ Языко } \\
инә \\
$\bigcirc$ энә/эйни/эзнә \\
D энә//инә \\
$\Delta$ энә \\
$\boldsymbol{\Delta}$ Үнә
\end{tabular}

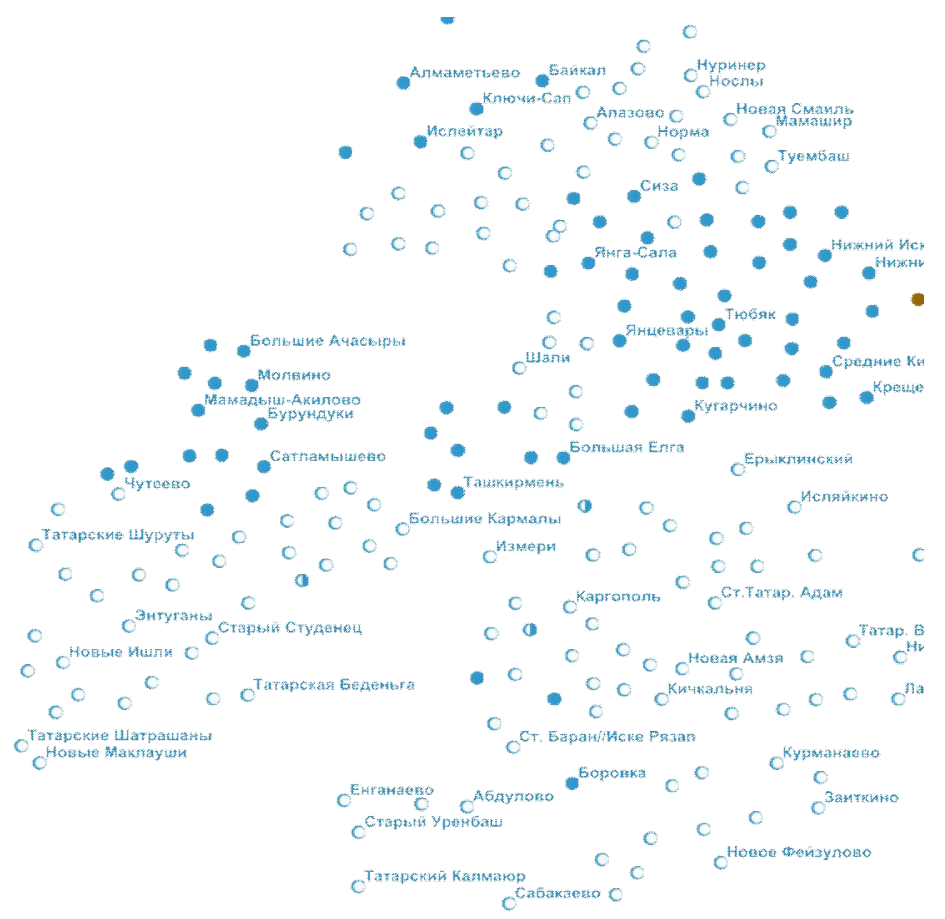

Сравни мамадышский: инә - литер. энә ‘иголка', ире — литер. эре ‘крупный’ [TХС 2008: 1, 30].

\section{$y$ в соответствии с литературным $о$}

Эти особенности отмечены в тексте [C]: сунгы - литер. соңъьы 'последний' [С: 4], суныннан - литер. соңыннан 'позже' [С: 7], нугытын - литер. ногытың 'твой горох' [С: 33], подобная рефлексация не была выявлена нами в других заказанских первых миссионерских книгах. Данное явление может быть соспоставлено с отмеченным соответствием для мишарской книги в статье [Норманская, Нуриева 2018: 105]: кутылырсынъ [Священная история 1862: 2] - литер. котылырсың 'освободишься', турсын [Священная история 1862: 1] - литер. торсын 'пусть встает, живет', муны [Священная история 1862: 1] литер. моны 'это', кушларь [Священная история 1862: 4] - литер. кошлар 'птицы'. В современных говорах кряшен Нижнего Прикамья и нагайбаков литературному o соответствует $y:$ тукмач — литер. токмач 'лапша', бутка - литер. ботка 'каша' [Баязитова 1986: 51]. Но все эти случаи относятся к рефлексам ПТю *u, которое вследствие волго-уральского «перелома гласных» дает в литературном татарском, а также в среднем диалекте и в большинстве диалектов башкирского $y$, а в мишарском памятнике сохраняется, по-видимому, архаическое состояние. В случае же суң, соң мы имеем дело с ПТю *soy, см. [Ахметьянов II: 168], для которого нуждается в объяснении сохранение $o$ в литературном татарском (заимствование из чагатайского?). Тем не менее, именно это соответствие наблюдается 
в современном мамадышском говоре, ср.: суң — литер. соң 'поздно', сунзгы - литер. соңзгы 'последний' [TXC 2008: 1, 30].

Во всяком случае, в стихах поэта Я. Емельянова отражена реальная диалектная особенность, характерная и для современных диалектов этого ареала.

bl в соответствии слитературным $о$

В тексте анализируемого сборника [C] встречаются спорадически явления делабиализации: быгаулар литер. богаулар 'оковы' [C: 22], башырыб — литер. баш орып 'склонив голову' [С: 4], мыннан — литер. моннан 'отсюда' [C: 7], пьшкырды — литер. пошкырды 'фыркнул' [С: 14], мында — литер. монда 'тут' [C: 16, 23, 33]; тылыммын — литер. тольммын 'косу' [23].

Для указательных местоимений эта черта была отмечена в других кряшенских книгах, рассмотренных ранее. В ряде случаев (в корнях указательных местоимений) звуку [o] 1-го слога соответствует неогубленное [bl]: былай [Евангелие 1908: 36; Учение 1897: 37] — литер. болай 'так, таким образом', [Евангелие 1908: 23; Учение 1897: 37] — литер. моны 'так'. Делабиализация огубленного о является характерной особенностью мишарских говоров подберезинских и чистопольских кряшен, например, в подберезинском говоре сылы — литер. сольл 'овес', бырынгы - литер. борынгы 'древний'; в чистопольском говоре: быдай - литер. бодай 'пшеница' [Баязитов 1986: 54]. В современных мамадышском и лаишевском говорах это соответствие в атласе не зафиксировано, хотя ср. в заказанско-кряшенских говорах мына; мынатыра: мынатыра бу карт сүләр сезгә - литер. монь бу карт сөйләр сезгә 'об этом расскажет вам этот старик' [ТХС 2008: 96, 98]; в лаишевском тексте мына (2 р.): мына труйсында зырлыйбыз инде — литер. моның турында жсырлыйбыз инде 'поем об этом' [ТХС 2008: 108].

Таким образом, анализ стихов Я. Емельянова показывает, что употребление $b l$ в соответствии с $o$ 150 лет назад встречалось не только в мишарских, но и в заказанских диалектах; такое употребление, повидимому, встречается и в настоящее время.

\section{Эпентеза}

Эпентеза, или вставка гласных внутри слова, по мнению исследователя татар-кряшен Ф. С. Баязитовой, в говорах кряшен встречается чаще, чем в других говорах татарского языка: күреше - литер. күрше 'сосед', карышы - литер. кариы 'напротив', жсөремей - литер. йөрми 'не ходит' и другие [Баязитова 1986: 54]. Вставка гласных внутри слова отмечена и в стихах Я. Емельянова, например: карышы - литер. каршы 'противоположные' [С: 31], тизерӓк — литер. тизрәк 'быстрее' [С: 33].

\section{Выпадение гласных $b l, e$}

В сборнике стихов Емельянова [C] подвержены выпадению (в специфических контекстах: взрывной + сонант, взрывной + сибилянт, сонант + сонант) гласные, которые соответствуют литер. татар. редуцированным $b l, e$ : блӓн — литер. белән 'c' [C: 4, 8], калтраб - литер. калтырап 'дрожа' [С: 8], ксӓмӓ - литер. кесәмә 'мой карман' [C: 11, 12, 15, 17, 33], мнӓ — литер. менә 'вот' [С: 16, 11], какна- литер. хакына 'из-за' [С: 12], блай - литер. болай 'так' [С: 13], утра - литер. утыра 'садиться' [С: 13], урнь литер. урыны 'место' [С: 18, 19], крӓшен — литер. керәшен 'кряшенский’ [С: 21], брӓ̈̈не — литер. берәүне 'никого' [С: 24, 35], гна - литер. гына 'только' [С:28] .

Это явление не было отмечено нами в заказанских миссионерских книгах, но часто встречается в мишарской: блай [Священная история 1862: 1] - литер. болай 'так', кииляргя [Священная история 1862: 1] литер. кешеләргә 'людям', брь [Священная история 1862: 1] - литер. бер 'один', блянь [Священная история 1862: 2] - литер. белән 'c', кряшинчя [Священная история 1862: 2] - литер. керәшенчә 'покряшенски', гна [Священная история 1862: 1] - литер. гына 'только'.

\section{ж в соответствии слитературным $\check{u}$}

К основным специфическим чертам кряшенских первых книг относится начальное жоканье. Оно характерно не только для заказанских, но и для мишарских книг. В текстах книг литературному $\check{u}$ в начале слова соответствует звонкий жс-, например: жулында [Священная история 1862: 3] - литер. юльлнда 'на дороге (пути)', жиланъ [Священная история 1862: 6] - литер. елан 'змея', жюкли [Священная история 1862: 7] - литер. йөкле 'беременная'. Жоканье считается характерной особенностью заказанского говора среднего диалекта [Баязитова 1986: 62]. Сравни в Атласе: http://atlas.antat.ru/atlas/maps.html?mapnom=33. 
Языковые явления

(1) редкие случаи употребления ж/дж

$\otimes$ начальное ж/й не отмечено (см. комментарии)

О̆ й/ж: жул//йул, жир//йир...

$\ominus$ й//ж в начале некоторых слов перед гласными ә, е, и

ж: жул, жир...

О й: йул 'дорога', йир 'земля'...

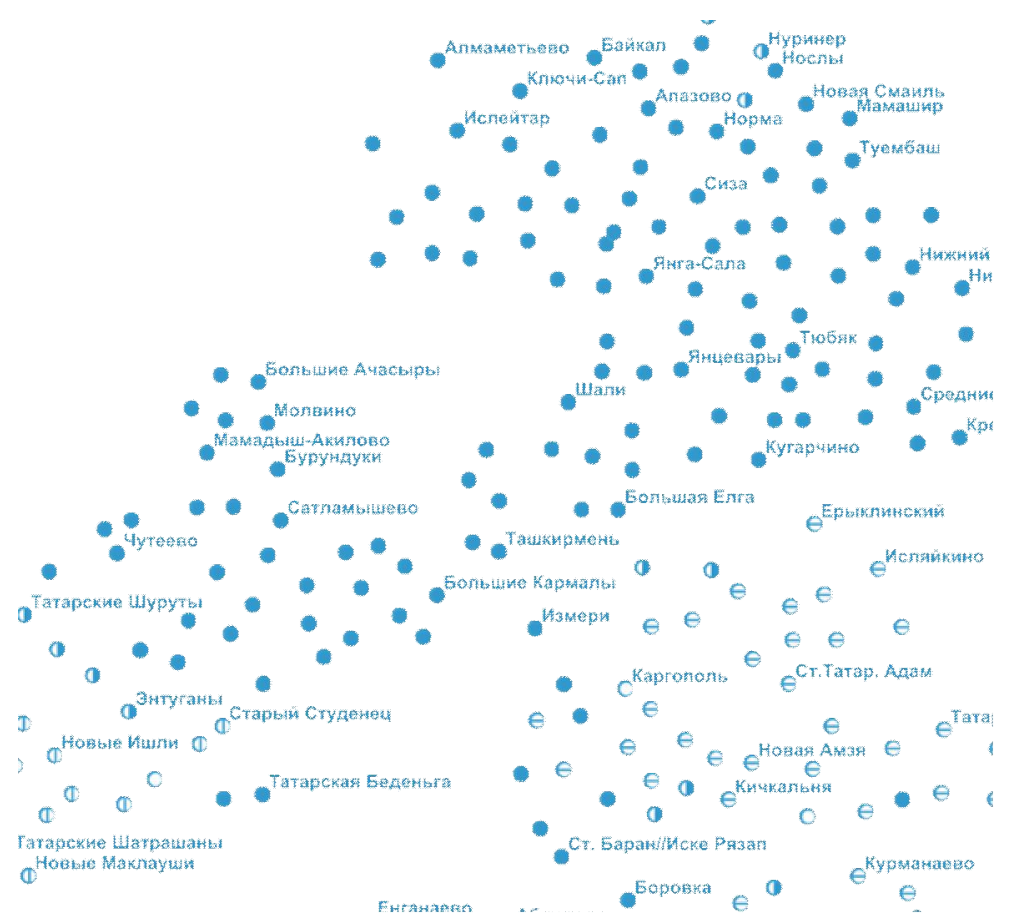

В сборнике [C] эта особенность представлена систематически во всех позициях, например, жалан литер. ялан 'всегда' [С: 2]; жаман - литер. яман 'скверный' [С: 2], жегет - литер. егет 'парень' [П], жӧзӧнӓ - литер. йөзенә 'на его лицо' [С: 4], жагылины - литер. ягыллыь 'любезно' [C: 4], жакларлар литер. якларлар 'поддержат' [С: 5], жарылсын - литер. ярылсын 'пускай растрескается' [С:7], жыгылмас - литер. егылмас 'не упадет' [С: 8], жукка - литер. юкка 'зря' [С: 9, П], жанымнан - литер. янымнан 'от меня' [С: 9], жаманныгынны жарырмын - литер. яманлыгыңны ярырмын 'твое дурное расколю' [С: 9], жауызын - литер. явызны 'злодея' [С: 10], ул жан керен жыуыб ӱтӓдер - литер. ул ж⿻ан керен юы үтәдер 'проникая отмывает грязь души' [С: 10], жул - литер. юл 'дорога'[С: 10], жыуаныр - литер. юаныр 'утешится' [С: 11].

Для текстов переводов богослужебных книг также характерно явление жоканья: в большинстве случаев литературному $\check{u}$ в начале и середине слова соответствует звонкий ж, например: ж⿻араульl - литер. яракль 'пригодный' [ЧДК: 4], жсактыдан - литер. яктылан 'света' [ЧДК: 6], ж⿻аратылган - литер. яратылган 'созданный' [ЧДК: 6], жсазык - литер. язык 'грех' [ЧДК: 8], ж⿻азыб - литер. языn ‘написав’ [ЧДК: 12], жсолар - литер. йолыр 'искупит' [ЧДК: 17], жук - литер. юк 'нет’ [ЧДК: 18], ж⿻ана - литер. яңза 'новый' [ЧДК: 15], жзәмерми - литер. ямерми 'не прячет' [ЧДК: 19], жсарына литер. ярына 'берегу' [ЧДК: 36], жуул - литер. юл 'дорога' [Евангелие: 36], ж⿻акшы - литер. яхшы 'хорошо'[Евангелие: 37] и др. Лишь в редких текстах зафиксированы примеры с анлаутным й: юрисен литер. йөрисещ 'ходишь'[ОП: 344], іерляргя - литер. жсирләргә 'в земли, страны' [ОП: 344]. Эта особенность представлена и в [Словарь 1880]: жыл - литер. ел 'год'; жылан - литер. елан 'змея'.

Такие примеры по [ДС 2009] спорадически встречаются и в современных говорах среднего диалекта татарского языка: касимовском, дубъязском и мамадышском: ср. сред. жсылан 'змея'; касим. жыылау 'плакать'; дубъяз., мамадыш. ж⿻ылқы жсыл 'год с теплой зимой' и другие. По современным полевым данным, «полное жоканье» характерно для заказанских кряшенских говоров, в частности, мамадышского и лаишевского, см. http://lingvodoc.ispras.ru/dictionary/3313/19304/perspective/3313/19305/view, http://lingvodoc.ispras.ru/dictionary/3313/13940/perspective/3313/13941/view; анализ и карту № 3 в статье [Дыбо 2020: С. 706-708].

$\kappa$ в соответствии с литературным $x$ в заимствованных основах

Активное употребление $\kappa$ вместо литературного $x$ (явление, связанное с адаптацией заимствованной арабо-персидской лексики) в разной степени распространено во всех говорах татарского языка. Как отмечают татарские диалектологи, это явление особенно характерно для кряшено-татарских говоров среднего диалекта [Махмутова 1978: 89].

Данное соответствие характерно для всех групп кряшен, имеет место во многих говорах среднего и мишарского диалектов и говорах сибирских татар: http://atlas.antat.ru/atlas/maps.html?mapnom=30. 
Языковые явления

О х/х: хат/хат, хәзер/хәзер...

к/к: қат/кат, қәзер/казер

х/х//к/к:хат//қат, хәзер//қәзер

$\ominus$ различные единичные случаи $\mathrm{x} / \mathrm{x} \sim \mathrm{K} / \mathrm{\kappa}$

А h: һат, һәзер...

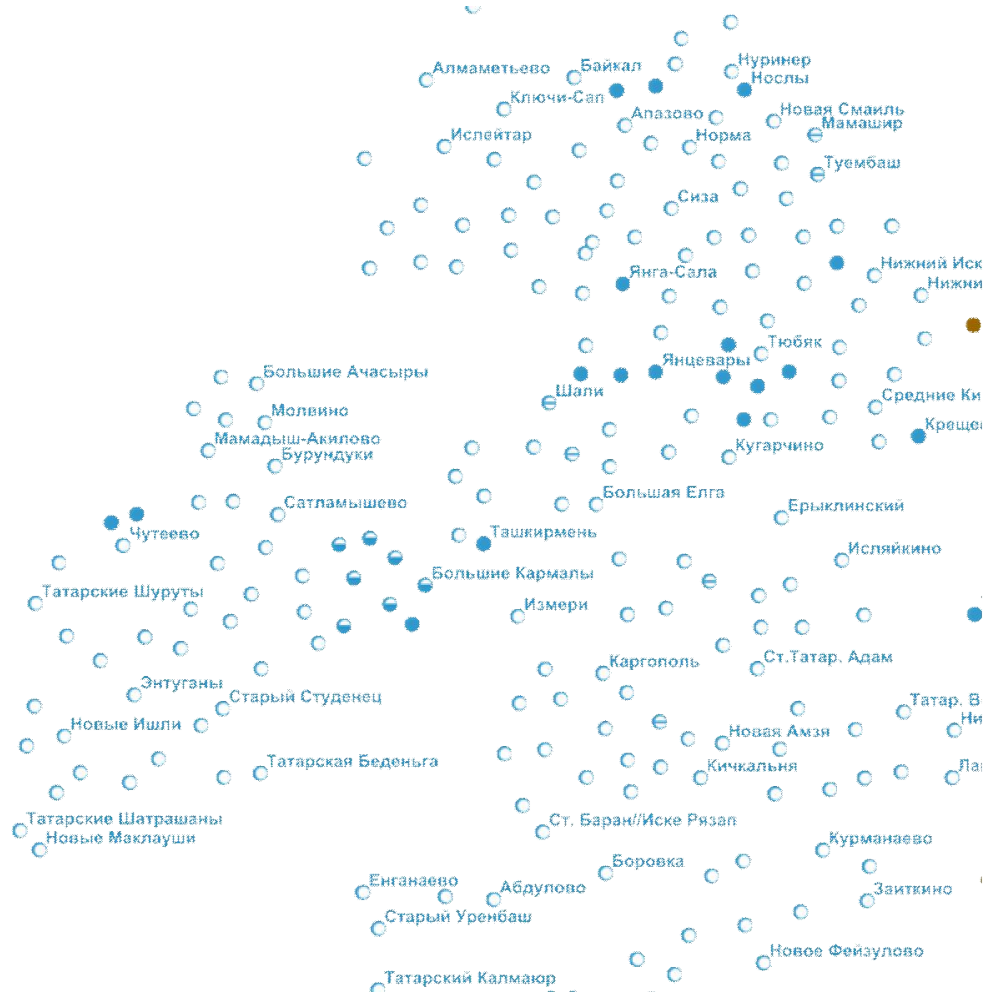

Что касается употребления согласных $\boldsymbol{\kappa}$ и $\boldsymbol{x}$ в сборнике [C], то здесь наблюдается активное использование Я. Емельяновым $\boldsymbol{\kappa}$ вместо литературного $\boldsymbol{x}$, например, катере - литер. хәтере 'память' [С: 2], калыклар - литер. халыклар 'народы' [С: 5], касерӓте - литер. хәсрәте 'печаль' [С: 6], закмӓттӓн литер. зәхмәттән 'от страдания' [С: 9], курлармын — литер. хурлармын 'оскорблю' [С: 9], курларлар литер. хурларлар 'опозорят' [C: 9], курлыюк - литер. хурльк ‘позор' [C: 10], закмӓтне - литер. зәхмәтне 'страдания' [С: 10], куш - литер. хуи 'прощай' [C: 11], какна - литер. хакына 'из-за' [C: 12], катынны литер. хатынны 'жену' [C: 13], калкын - литер. халкын 'народ' [C: 16].

Соответствие $\boldsymbol{x} \sim \boldsymbol{\kappa}$ наблюдается и в других переводных религиозных текстах. например: курльій литер. хурлый 'оскорбляет' [Евангелие: 23], катын - литер. хатын 'жена' [ЧДК: 26], калык — литер. халык 'народ' [Евангелие: 41], каста - литер. хаста 'больной' [Евангелие: 21], кызмят - литер. хезмәт 'труд' [Евангелие: 21] и др. Соответствие $\boldsymbol{x} \sim \boldsymbol{\kappa}$ наиболее систематично наблюдается в кряшенских говорах и в говоре пермских татар [МТД 1962: 30].

\section{0 в соответствии с литературным $h$ в заимствованных основах}

Звук $h$ в современном татарском языке встречается только в заимствованных словах, а в говорах кряшен вовсе не употребляется. Действительно, в рассматриваемом памятнике фарингальный согласный $h$ в начале слов выпадает. Например: $\ddot{a} p$ - литер. $h ә p$ 'каждый' [C: 2, 5, 6, 10, 21, 25], ич бер чакта литер. һич бер чакта 'никогда' [C: 2, 7, 8, 12].

Подобное языковое явление наблюдается и в других кириллических книгах: $\ddot{p}-$ литер. $h ә p$ 'каждый' [ЧДК: 7], ич-кем - литер. һичкем 'никто' [ЧДК: 17], ичтя - литер. һичтә 'никак' [ЧДК: 20], ава - литер. hава 'погода' [Евангелие: 39], ӓммя - литер. һәммә 'все' [Евангелие: 37] и др.

Фарингальный звук $h$ в анлауте арабских заимствований в современных говорах кряшен всегда опускается [TХC 2008: 95]. В Атласе татарских народных говоров эта особенность не отражена.

\section{$n$ в соответствии с литературным $\phi$ в заимствованных основах}

В тексте анализируемого поэтического сборника $[\mathrm{C}]$ губно-зубной щелевой звук $\phi$ в арабо-персидских заимствованиях заменяется смычным согласным $n$ : пайдa - литер. файда 'польза' [C: 15], кӧпӧрлӧк - литер. көферлек ‘богохульство' [С: 23], пӓриштӓн - литер. фәрештәң 'ангел' [С: 34]. Это явление встречается и в других первых кириллических книгах: пӓриштя - литер. фәрештә 'ангел' [ЧДК: 32], пайдасыз — литер. файдасыз ‘бесполезный’ [Евангелие: 44]

В настоящее время аналогичное соответствие в основном характерно для речи старшего поколения в определенных районах, см. http://atlas.antat.ru/atlas/maps.html?mapnom=65. 
Языковые явления

ф п как система: пайда, Сапа, Нәписә

ф сохраняется: файда 'польза', Сафа 'и.с.', Нәфисә 'и.с.'

- ф//п: файда//пайда, Сафа//Сапа, Нәфисә//Нәписә

$\ominus$ ф П наблюдается редко

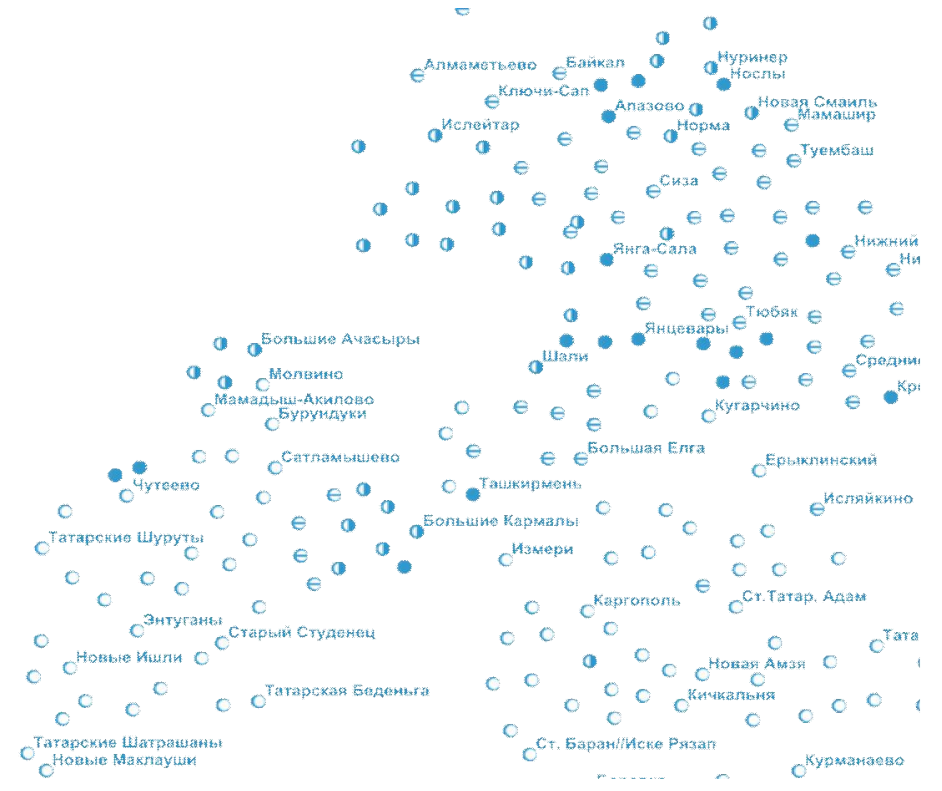

бв соответствии с литературным в в заимствованных основах:

В тексте [C] соответствие $\sigma \sim$ в встречается в арабских заимствованиях: багыты - литер. вакыты 'время' [C: 5, 10], багытта - литер. вакытта 'время' [С: 10], кайбан - литер. хайван 'животное' [С: 34].

В кириллической мишарской книге в аналогичных заимствованиях представлено такое же соответствие: багытта - литер. вакытта 'время' [Священная история 1862: 1], хайбаннаръ - литер. хайваннар 'звери' [Священная история 1862: 5]. Можно отметить, что аналогичные примеры зафиксированы в говоре заказанских кряшен: багыт - литер. вакыт 'время' [ТХС 2008: 95]. Такое соответствие имеет место и в говорах среднего диалекта, цокающих говорах мишарского диалекта, главным образом в речи старшего поколения [Махмутова 1978: 72].

\section{$б$ в соответствии с литературным $n$}

По всему тексту книги $[\mathrm{C}]$ в показателе деепричастия форма с соответствием -б (литературный $-n)$ встречается системно, примеры: сыгылыб, башырыб калыгыз - литер. сыгылыл, баш орып калыгыз 'оставайтесь прогнувшись, склонив голову' [С: 4], биренеб - литер. бирелеп 'усердно' [С: 5], диб литер. дип 'сказав' [С: 6], каушатыб - литер. каушатып 'смутившись' [С:8], шаулаб — литер. шаулап ‘бурно' [С: 8], ыулаб - литер. улап 'зазывая’ [C: 8], каушаб, калтраб жыгылмас - литер. каушап, калтырап егылмас 'смутившись, дрожа не упадет' [C: 8], короб — литер. корып 'воздвигая' [С: 9], кӱреб литер. күреп 'увидев' [С: 11], абтраб - литер. aптырап 'в недоумении' [С: 12], арыб — литер. apыn 'устав' [С: 14], жирӓнеб басыб - литер. жсирәнеп басып 'сдавливая брезгуя' [С: 21], шаркылдаб кӧлӧn - литер. шаркылдап көлеп 'хохоча' [С: 7, 22], басыб - литер. басып 'сдавливая' [С: 22] и др. Также с -б на конце выписывается арабское заимствование (жауаб - литер. ж⿻авап 'ответ' [C: 21]) и односложные тюркские корни, оканчивавшиеся на *-p (чёб - литер. чүn 'мусор' [C: 17], кёб - литер. күn 'много' [C: 31], табмыйсын - литер. тапмыйсың 'не находишь' [С: 21]) и др.

Эта черта характерна и для других кириллических книг на татарском, казахском и башкирском языках [Евангелие 1908; Священная история 1862; Шаймердинова 2016: 129-132; Дыбо, Норманская 2016: 144; Норманская, Каримова, Экба 2017: 49]; пока неясно, соответствует ли это какой-то фонетической реальности или же чисто орфографический прием.

\section{$H$ в соответствии с литературным $л$}

В текстах стихотворений в [C] после носовых согласных переднеязычный $л$ подвергается прогрессивной ассимиляции, например, в аффиксах -ла, -лә, -льl, -ле, -лар: саннар — литер. санлар 'почитать' [С: 4], саннагыз - литер. санлагыз 'уважайте' [С: 2], аннагыз - литер. аңлагыз 'поймите' [С: 2], тыннагыз литер. тыңлагыз 'слушайте' [С: 2], жагымны — литер. ягымлы 'любезно' [С: 4], саннау — литер. санлау 'уважение' [С: 4], саннаучь - литер. санлаучьы 'уважающий' [С: 4], аннғарлар - литер. аңларлар 'поймут' [C: 5], даннарлар — литер. данларлар 'прославят' [C: 5], даннарга — литер. данларга 'прославлять' 
[C: 6], женне - литер. ж⿻енле 'бесноватый' [C: 18], аннатыб биргӓч - литер. аңлатып биргәч 'после объяснения' [С: 21], жангышларын - литер. ялгышларын 'ошибки' [С: 26], жӥннӓб — литер. юньләп 'старательно' [С: 33].

Ассимиляция $\boldsymbol{\boldsymbol { H }} \sim \boldsymbol{л}$ наблюдается и в других заказанских и мишарских переводных религиозных текстах: былар ирле катынны икесе дя - литер. булар ирле-хатынлы икесе дә 'эти двое муж и жена' [Земная жизнь: 6]; исерткеч эчемнек эчмяскя тейеш — литер. исерткеч эчемлек эчмәскә тиеш 'не должен пить спиртное' [Земная жизнь: 7]; жирдян арь тюрлю три жаннык чыксын - литер. жсирдән һәр төрле тере жсанлы чыксын 'пусть из земли поднимутся живности' [Священная история 1862: 5]

Данное соответствие редко встречается в татарских говорах, но оно характерно для говоров кряшен Заказанья и нагайбаков [TXC 2008: 127; 159], cp. http://atlas.antat.ru/atlas/maps.html?mapnom=55; также ср. подробный разбор явления в [Норманская, Гаджиева 2020] и в [Дыбо и др. 2020:1422 -1424; карта 5]

Итак, в результате анализа графико-фонетических особенностей в тексте стихотворений Я. Емельянова в сравнении с богослужебными переводными текстами и современными диалектами выявлены следующие типы особенностей:

1) есть в других заказанских первых книгах и есть в современном мамадышском и лаишевском говорах: а) же в соответствии с литературным й; б) $\boldsymbol{\kappa}$ в соответствии с литературным $\boldsymbol{x}$; в) $\boldsymbol{n}$ в соответствии с литературным $\boldsymbol{\phi}$; г) б в соответствии с литературным $\boldsymbol{n}$; д) $\boldsymbol{\boldsymbol { H }}$ в соответствии с литературным л; е) губная гармония; ж) употребление дифтонгов;

2) есть в других заказанских первых книгах, но нет в современном мамадышском и лаишевском по Атласу; однако есть по материалам [ТХС 2008]: а) в в соответствии с литературнымм о;

3) нет в других заказанских книгах, но есть в мишарских и в современных мамадышском, дубъязском, лаишевском говорах: а) б в соответствии с литературным в; б) и в соответствии с литературным $\boldsymbol{e}(\boldsymbol{э})$; в) у в соответствии с литературнымм о;

4) не отмечено в совр. мамадышском, нет в заказанских первых книгах, но есть в первых мишарских книгах и современных диалектах: а) выпадение гласных $\boldsymbol{b l}, \boldsymbol{e}$.

Подводя итог рассмотрения графико-фонетических особенностей текстов Якова Емельянова, можно отметить, что его книга несколько отличается от первых заказанских переводов богослужебной литературы, рассмотренных нами ранее, ср. [Нуриева 2015; Норманская, Нуриева 2017], в которых не были отмечены особенности 3-4 типов. Все эти особенности характерны для первой книги на мишарском диалекте [Священная история 1862]. Но, в отличие от нее, черты 3-го и 4-го типов в стихах Якова Емельянова встречаются весьма редко и спорадически, а в [Священная история 1862] они представлены регулярно. Следует также отметить, что особенности 3-го типа представлены в современном мамадышком и лаишевском говорах. Таким образом, по большинству графико-фонетических особенностей поэзия Якова Емельянова совпадает с современными говорами того региона, где он родился и жил.

\section{Морфологические особенности}

Морфологические особенности языка Я. Емельянова, отличающие его от татарского литературного языка, полностью соответствуют современным диалектам заказанских татар-кряшен.

Аффиксы родительного падежа

В качестве характерных черт говора заказанских кряшен, зафиксированных в сборнике [C], можно отметить аффиксы родительного падежа -нын, -нен в именах существительных и местоимениях. Примеры: Ашынның тӓмен белмӓсен - литер. Ашыңның тәмен белмәсен 'Пусть не знает вкус твоей пищи' [C: 34]. Уйсыз ирнен ауызыннан - литер. Уйсыз ирнең авызыннан 'Изо рта бездумного мужчины' [C: 19]. Безнен жакка чӓйнен чӥбен жӧклӓб-ӝ̈клӓб тарата - литер. Безнең якка чәйнең чүбен йөкләпйөкләп тарата 'Чайный мусор в нашу сторону загружая отправляет' [С: 16] и др.

Родительный падеж на -нын, -нен характерен и для заказанских богослужебных книг: Шушы кечкенялярнен ӧирянеӱчелеге какына бер гня сауыт салкын сыу эчерткян кеше ...сауабын алмый калмас литер. Шушы кечкенәләрнең өйрәнүе өчен бер генә савыт салкын су эчерткән кеше савабын алмый калмас 'тому, кто напоит стаканом холодной воды маленьких обучающихся воздастся' [Евангелие 1908: 29]; жсазыклы кешелярнен дусы - литер. языкль кешеләрнең дусты 'друг грешних людей' [Евангелие 1908: 31]; кюкнен, жирнен Ходайы - литер. күкнең, жирнең Ходае 'Бог неба и земли' [Евангелие 1908: 31]; бакчанын арь брь агачыннан жимишь алыбъ аша - литер. бакчаның һәрбер агачыннан жсимеш aльпn аша 'ешь яблоко с каждого дерева' [Земная жизнь1900: 7]. 
По [Баязитова 1986: 75], [ТХС 2008: 97] такие показатели родительного падежа свойственны всем говорам кряшен, ср. в Атласе http://atlas.antat.ru/atlas/maps.html?mapnom=54.

\section{Аффикс 1 л. ед. ч. будущего времени}

В спряжении будущего времени на - $p,-a p,-ә p$ в тексте стихотворений глаголы первого лица единственного числа имеют аффикс -ымм, -ем (вместо литературного -мын, -мен). Примеры: тоймастын тартыб жыгарым диб - литер. тоймастан тартып егармын дип. 'сказав, уроню незаметно' [С: 9]; жарар, бӓбкӓм, барым - литер. ярар, бәбкәм, барырмын 'ладно, дитя, пойду’ [С: 28].

Эта черта была отмечена в других кряшенских книгах: кюктяге Атам алдында ӓйтеб белдеремлитер. күктәге Атам алдында әйтеп белдерермен 'перед небесным Отцом выскажу' [Евангелие 1908: 29]; мин сезне тынычландырым - литер. мин сезне тынычландырырмын 'я вас успокою' [Евангелие: 31 ].

В [Баязитова 1986: 95], [ТХС 2008: 100] отмечается, что это явление характерно и для современных кряшенских говоров, например: мин барым - литер. барырмын 'я пойду'. Но в речи среднего поколения и моложе под влиянием литературного языка может употребляться и форма -мын, ср. [Махмутова 1978: 144].

\section{Аффиксы инфинитива}

В тексте стихотворений зафиксированы две формы инфинитива. Наряду с наиболее частотной формой на -рга, характерной и для татарского литературного языка, например, ашарга жибӓреб алдырдык литер. ашарга жсибәреп алдырдык 'чтобы покушать заказали' [С: 12], в 2 словоформах зафиксирован аффикс инфинитива на -мага: байга бардым алмага - литер. байга бардым алырга 'пошел получить к богачу' [C: 11]; артыкларны салмага - литер. артыкларны салырга 'лишнее класть' [С: 12].

По [Баязитова 1986: 119-120], инфинитив -мага характерен как для некоторых говоров кряшен, так и для касимовского, параньгинского, заказанского, карино-глазовского говоров среднего диалекта и диалекта пермских татар, cp. карту http://atlas.antat.ru/atlas/maps.html?mapnom=90, где эта форма представлена на западе распространения мишарских говоров, в касимовском, бастанском, куршинском, нукратском, параньгинском, частично в дубъязском, балтачском говорах татарского языка. Ограниченное употребление отмечено и на территории распространения бугурусланского говора (Оренбуржье).

По данным карты, инфинитив -мага не встречается в современных мамадышском и лаишевском говорах, но, по материалам [TХC 2008: 33], присутствует в определенных выражениях: алмага килдем литер. алырга килдем 'пришла забрать'. Это может свидетельствовать о том, что форма из этих говоров постепенно исчезает - в стихах Якова Емельянова она регистрируется всего 2 раза. Ср., впрочем, данные об употребительности ее в современных (точнее, 2-й половины XX в.) заказанских кряшенских говорах в [TXC 2008: 103].

Значимым является и использование в стихах Я. Емельянова формы -рга в соответствии с литературным татарским именем действия на $-y,-Y$ в дательном падеже (-гa), например: мин кайтырга самауар куй - литер. мин кайтуга самавыр куй 'сказал, поставь самовар к моему приходу' [С: 12]; мин кайтырга самауар бик шатырдаб кайнаган - литер. мин кайтуга самовар бик шатырдап кайнаган 'к моему приходу самовар с треском закипел' [С: 12]. Эта черта по [Баязитова 1986: 119], [ТХС 2008: 103] является важной диалектной особенностью говора заказанских кряшен.

Итак, видно, что морфологический строй языка стихотворений Я. Емельянова очень близок к современному татарскому литературному языку, а все отличия характерны для мамадышского и лаишевского кряшенских говоров татарского языка.

\section{Лексика}

Лексика языка сборника [C], в основном, совпадает с лексикой татарского литературного языка, однако есть специфические особенности, как было отмечено выше, по нашим подсчетам они малочисленны (90 лексических единиц) и в большинстве своем зафиксированы по [ДС 2009] в кряшенских говора заказанского диалекта. Приведем некоторые примеры, указывая на параллели в мамадышском:

— жалан [С: 4, 24] - мамад. жсалан 'постоянно' [ДС 2009: 178] — литер. һәрвакыт: Ӱгетен жалан тыннагыз 'Слушайте его наставления постоянно' - литер. Үгетен hәрвакыт тыңлагыз 'Слушайте его наставления каждый раз' [С: 4]. Кӧн дя ызгыш, жалан ӓр жебкертте инде жанымны 'Каждый день 
ссоры, постоянные руганья, излохматили мою душу' [С: 24] - литер. Көн дә ыззыи, hәрвакыт әрләиү телгәләде инде ж⿻анымны 'Каждый день ссоры, постоянные руганья, ранили мою душу’ [С: 24].

— инӓл [С: 24] — мамад. инәлү 'умолять' [ДС 2009: 211] - литер. ялын: Кайгыр, кӧйӧн. Интек, инӓл 'Переживай, печалься. Мучайся, умоляй' - литер. Кайгыр, көен. Интек, ялын 'Переживай, печалься. Мучайся, умоляй' [C: 24].

— кнӓген [С: 25] — мамад. кенәген 'вчера' [ДС 2009: 298] - литер. кичә: Кнӓген ӱлде бер тауык, бӧгӧн берсе чирлӓгӓн, син аней сизмӓсен, безнен клӓулӓр кирелӓгӓн 'Вчера умерла одна курица, сегодня одна заболела, ты, мама, не чувствуешь, наши желания обернулись вспять' - литер. Кичә үлде бер тавык, бүген берсе чирләгән, син, әни, сизмисен, безнен теләкләр кабул булмаган 'Вчера умерла одна курица, сегодня одна заболела, ты, мама, не чувствуешь, наши желания не сбылись’ [С: 25].

Интересно, что графический облик арабо-персидских заимствований в стихах Я. Емельянова часто отличается от литературного. Кроме уже описанных выше различий, это следующие:

а) употребление $a$ в соответствии с лит. ә: катер — литер. хәтер 'память' [С: 5], касрӓт - литер. хәсрәт 'горе' [С: 6, 25], закмят - литер. зәхмәт 'порча' [C: 9, 10, 19]; хальфа — литер. хәлфә 'учитель' [C: 20], казер - литер. хәзер 'сейчас' [C: 16, 29], жаза - литер. жсәза 'наказание' [С: 21], хайла - литер. хәйлә 'хитрость' [С: 21], ракмӓт — литер. рәхмәт 'спасибо' [С: 28, 32], .

б) другие отличия гласных: гёмер — литер. гомер 'жизнь' [С: 4], кӓдер - литер. кадер 'уважение'.

В целом, такая адаптация заимствований характерна и для других первых кириллических книг, и для современных кряшенских диалектов.

\section{Заключение}

Анализ фонетических, морфологических и лексических особенностей текстов поэтического сборника [C] священника Якова Емельянова, родившегося в Лаишевском уезде и проживавшего на момент создания стихов в Мамадышском уезде Казанской губернии, показывает, что текст весьма близок к богослужебным и учебным первым кириллическим книгам, написанным на татарском языке. С точки зрения наличия сингармонизма в большинстве слов с $o, \ddot{o}$ в первом слоге [C] наиболее близок книгам [Словарь 1876; Требник 1881], системы которых были разобраны в [Норманская, Нуриева 2018]. Но есть ряд особенностей, пока не выявленных нами в заказанских миссионерских книгах: а) $б$ в соответствии с литературным 6 , б) $u$ в соответствии с литературным $e$ (э); в) $y$ в соответствии с литературным $o$; г) выпадение гласных $b l$, e. Учитывая, что черты, перечисленные в пунктах а), б), в), характерны для современных мамадышского и лаишевского говоров, мы предполагаем, что эти особенности реально присутствовали в речи носителей-кряшен в XIX в., но были нивелированы в миссионерских книгах, а в стихах Якова Емельянова представлены реальные разговорные варианты слов того времени.

С точки зрения морфологических отличий от литературного татарского языка говор стихов Якова Емельянова также близок к мамадышскому и лаишевскому говорам. С точки зрения лексических особенностей стихи Якова Емельянова также представляют ценный источник по мамадышскому и лаишевскому говорам татарского языка.

В настоящее время, к сожалению, не удается точно определить, какой говор, мамадышский или лаишевский, лег в основу стихов (поскольку по имеющимся диалектологическим источникам сложно выяснить различия этих говоров). Возможно, дальнейшие полевые исследования позволят выявить более полный список различий между ними, соотнести их с текстом стихов Якова Емельянова и уточнить диалектную принадлежность текста.

\section{Сокращения}

С - Стихи на крещено-татарском языке Я. Емельянова

П - Письма Я. Емельянова В. Тимофееву и Н. Ильминскому

сред. - средний диалект татарского языка

касим. - касимовский говор среднего диалекта татарского языка

дубъяз. - дубъязский говор среднего диалекта татарского языка

мамадыш. - мамадышский говор среднего диалекта татарского языка

ПТю - пратюркский язык 


\section{Литература}

Баженов, 1847 - Баженов Н. Казанская история: в 3-х частях. Казань, 1847. \{Bazhenov N. History of Kazan: in 3 parts. Kazan, 1847.\}

Баязитова 1986 - Баязитова Ф. С. Говоры татар-крящен в сравнительном освещении. М., 1986. \{Bayazitova F. S. Subdialects of the Kryashen Tatars in comparative coverage. M., 1986.\}

Баязитова, Хайбуллина 2013 - Баязитова Ф. С., Хайбуллина Г. Х. Язык и культура: Этнолингвистические и этноконфессиональные особенности татарских говоров Западного Закамья Татарстана. Казань, 2013. \{Bayazitova F. S., Khaybullina G. Kh. Language and Culture: Ethnolinguistic and ethno-confessional features of the Tatar subdialects of Western Zakamye of Tatarstan. Kazan, 2013.\}

Баязитова 1997 - Баязитова Ф. С. Крәшеннәр. Тел үзенчәлекләре һәм йола ижаты. (Кряшены. Языковые особенности и обряды). Казан, 1997. \{Bayazitova F. S. Kryashen Tatars. Linguistic features and ceremonies. Kazan, 1847.\}

Воробьев 1953 - Воробьев Н. И. Казанские татары. Казань, 1953. \{Vorobyev N. I. Kazan Tatars. Kazan, 1953.\}

ДС 1969 - Диалектологический словарь татарского языка. Казань, 1969. \{Dialectological dictionary of the Tatar language. Kazan, 1969.\}

ДС 2009 - Татар теленең зур диалектологик сүзлеге. Казан, 2009. \{Dialectological dictionary of the Tatar language. Kazan, 2009.\}

Дыбо 2020 - Дыбо А. В., Абубакирова Л. Ф., Айбазова З. К., Зимин М. М., Коровина Е. В., Мальцева В. С., Мудрак О. А., Ренковская Е. А., Савельев А. В., Хисамов О. Р., Шаров А. В., Шеймович А. В. Новые результаты в генеалогической классификации тюркских диалектов («случаи с аффрикатами») // Oriental Studies. 2020,13 (3). С. 696 - 713. \{Dybo A. V., Abubakirova L. F., Aibazova Z. K., Hisamov O. R., Korovina E. V., Maltseva V. S., Mudrak O. A., Renkovskaya E. A., Savelyev A. V., Sharov A. V., Sheimovich A.V., Zimin M. M. Some New Results in the Genealogical Classification of Turkic Dialects: 'Cases of Affricates' // Oriental Studies. 2020, 13(3). P. 696-713.\}

Дыбо и др. 2020 - Дыбо А. В., Абубакирова Л. Ф., Зимин М. М., Коровина Е. В., Кочакаева З. К., Шаров А. В. Еще раз о формах показателя множественного числа в тюркских языках. Oriental Studies. 2020,13 (5). C. 1415 - 1437. https://doi.org/10.22162/2619-0990-2020-51-5-1415-1437 \{Dybo A. V., Abubakirova L. F., Kochakaeva Z. K., Korovina E. V., Sharov A. V., Zimin M. M. Once Again about Allomorphism of the Plural -lar in Turkic Languages // Oriental Studies. 2020, 13(5). P. 1415-1437. https://doi.org/10.22162/2619-0990-2020-51-5-1415-1437\}

Дыбо, Норманская 2016 - Дыбо А. В., Норманская Ю. В. Первые кириллические книги на казахском языке как источники для изучения истории диалектов и создания литературной нормы // Урало-алтайские исследования. 2016, 4 (23). C. 138-153. \{Dybo A. V., Normanskaya Yu. V. First Cyrillic books in Kazakh language as sources for studying the history of dialects and creating a literary norm // Ural-Altaic Studies. 2016, 4(23). P. 138-153.\}

Евангелие 1866 - Святое Евангелие Господа нашего Иисуса Христа на народно-татарском языке. Казань, 1866. \{Holy Gospel of Our Lord Jesus Christ in Tatar. Kazan, 1866.\}

Евангелие 1908 - Святое Евангелие господа нашего Иисуса Христа на татарском языке. Казань, 1908. \{Нoly Gospel of Our Lord Jesus Christ in Tatar. Kazan, 1908.\}

Ешевский 1900 - Ешевский С. В. Сочинения по русской истории. М., 1900. С. 202-362. \{Yeshevsky S. V. Works on Russian History. Moscow, 1900. P. 202-362.\}

Жәләй 1954 - Жәләй Л. Татар теленең урта диалекты буенча монография (Заляй Л. Монография по среднему диалекту татарского языка). Казан, 1954. \{Zalay L. Monograph on the average dialect of the Tatar language. Kazan, 1954.\}

Земная жизнь 1900 - Земная жизнь Господа нашего Иисуса Христа. Казань, 1900. \{The earthly life of our Lord Jesus Christ. Kazan, 1900.\}

Загидуллин 2014 — Загидуллин И. К. Татарское национальное движение в 1860-1905 гг. Казань, 2014. \{Zagidullin I. K. Tatar national movement in 1860-1905. Kazan, 2015.\}

Загидуллина 2013 - Загидуллина Д. Ф. Просветительство и татарская литература // История татар с древнейших времен. T. VI. Казань, 2013. \{Zagidullina D. F. Education and Tatar literature // History of the Tatars from ancient times. Vol. VI. Kazan, 2013.\}

Ильминский 1892 - Ильминский Н. И. Избранные места из педагогических сочинений. Казань, 1892. \{Ilminsky N. I. Selected parts from pedagogical essays. Kazan, 1892.\}

Ильминский 1887 - Ильминский Н. И. Казанская центральная крещено-татарская школа. Материалы для истории христианского просвещения крещенных татар. Казань, 1887. \{Ilminsky N. I. Kazan central Krayshen-Tatar school. Materials for the History of Christian education of Christianized Tatars. Kazan, 1887.\}

Ильминский 1884 - Ильминский Н. И. К истории инородческих переводов. Казань, 1884. \{Ilminsky N. I. Tо the History of non-Slavic translagtions. Kazan, 1884.\}

Ильминский 1883 - Ильминский Н. И. Опыты переложения христианских вероучительских книг на татарский и другие инородческие языки в начале текущего столетия. Казань, 1883. \{Ilminsky N. I. The experiences of translating Christian teaching books into Tatar and other foreign languages at the beginning of this century. Kazan, 1883.\} 
Ильминский 1869 - Ильминский Н. И. Сборник документов и статей по вопросу об образовании инородцев. СПб., 1869. \{Ilminsky N. I. Collection of documents and articles on the issue of the non-Slavic education. St. Petersburg, 1869.\}

Исхаков 2015 - Исхаков Р. Р. Православные религиозные институты кряшен (крещеных татар) ВолгоУральского региона во второй половине XIX - начале XX в. // Грамота. Тамбов, 2015. 11 (61). С. 71-74. \{Iskhakov R. R. Orthodox religious institutes of Kryashen (Christianized Tatars) of the Volga-Ural region in the second half of the 19th and early 20th centuries // Gramota. Tambov, 2015. 11(61). P. 71-74.\}

Малов 1872 - Малов E. А. Очерк религиозного положения крещеных татар, подвергшихся влиянию магометанство (миссионерский дневник). Казань, 1872. \{Malov E. A. Essay on the religious situation of Christianized Tatars influenced by Mohammedanism (missionary diary). Kazan, 1872.\}

Махмутова 1978 - Махмутова Л. Т. Опыт исследования тюркских диалектов (мишарский диалект татарского языка). M., 1978. \{Mahmutova L. T. A study in Turkic dialects (the Mishar dialect of Tatar). Moscow, 1978.\}

Машанов 1875 - Машанов М. А. Заметка о религиозно-нравственном состоянии крещенных татар Казанской губернии Мамадышеского уезда, Казань, 1875. \{Mashanov M. A. Article on the religious and moral condition of the Christianized Tatars of the Kazan province of Mamadysh district. Kazan, 1875.\}

Миллер 1791 - Миллер Г. Описание живущих в Казанской губернии языческих народов, яко то черемис, чуваш и вотяков. СПб., 1791. \{Miller $G$. Description of pagan peoples living in the Kazan province, like Cheremis, Chuvash and Votyakov. St. Petersburg, 1791.\}

МТД 1962 - Материалы по татарской диалектологии. Казань, 1962. \{Materials on Tatar dialects. Kazan, 1962. \}

Мухаметшин 1977 - Мухаметшин Ю. Г. Татары-кряшены. М., 1977. \{Mukhametshin Yu. G. Tatar-Kryashens. Moscow, 1977.\}

Никольский 1905 - Никольский Н. В. Переводческая комиссия в Казани и просветительская деятельность среди инородцев. Казань, 1905. \{Nikolsky N. V. Translation commission in Kazan and educational activities among nonSlavic population. Kazan, 1905.\}

Норманская, Гаджиева 2020 - Норманская Ю. В., Гаджиева А. А. Как изменилась форма показателя множественного числа в тюркских языках за последние 150 лет // Oriental Studies. 2020, 13 (4). C. 1121-1134. \{Normanskaya Yu. V., Gadzhieva A. A. How has the plural form changed in Turkic languages over the past 150 years // Oriental Studies. 2020. 13(4). P. 1121-1134.\}

Норманская, Каримова, Экба 2017 - Норманская Ю. В., Каримова Р. Н., Экба 3. Н. В. В. Катаринский - автор первой кириллической книги на башкирском языке // Урало-алтайские исследования. 2017, 2 (25). С. 46-52. \{Normanskaya Yu. V. Karimova R. N., Ekba Z. N. V. V. Katarinsky - the author of the first Cyrillic book in Bashkir language // Ural-Altaic Studies. 2017, 2(25). P. 46-52.\}

Норманская, Нуриева 2018 - Норманская Ю. В., Нуриева Ф. Ш. Диалектные особенности первых кириллических книг на татарском языке // Вопросы тюркской филологии. Вып. 12. 2018. С. 95-111. \{Normanskaya Yu. V., Nurieva F. Sh. Dialectal features of the first Cyrillic books in the Tatar language // Questions of Turkic philology. Vol. 12. 2018. P. 95-111.\}

Нуриева 2015 - Нуриева Ф. Ш. Диалектная основа книг на «крещено-татарском» языке второй половины ХІХ века // Урало-алтайские исследования. 2015, 2 (17). С. 67-74. \{Nurieva F. Sh. Dialectal basis of the books in "Kresheno-Tatar" language of the second half of the $19^{\text {th }}$ century // Ural-Altaic studies. 2015, 2(17). P. 67-74.\}

Нуриева 2017 - Нуриева Ф. Ш. Языковой памятник говора сергачских мишарей: текст исповеди XIX века // Урало-алтайские исследования. 2017, 3 (26). С. 167-179. \{Nurieva F. Sh. The language monument of the dialect of Sergach Mishars: the text of the 19th century confession // Ural-Altaic Studies. 2017, 3(26). P. 167-179.\}

ОП 1883 - Опыты переложения христианских вероучительных книг на татарский и другие инородческие языки в начале текущего столетия. Материал для истории православного русского миссионерства. Казань: Типография императорского ун-та,1883. \{A record of translating the Christian books of creed in Tatar and other non-Russian languages in the beginning of the present century. Materials for the history of the Orthodox Russian missionary work. Kazan: Imperial University press, 1883.\}

Перетяткович 1882 - Перетяткович Г. И. Поволжье в XVII-в начале XVIII века (Очерки из истории колонизации края). Одесса, 1882. \{Petryatkovich G. I. The Volga region in $17^{\text {th }}$ and at the beginning of 18 th centuries (Essays from the history of the colonization of the region). Odessa, 1882.\}

Рыбушкин 1849 - Рыбушкин M. . Краткая история города Казани. Казань, 1849. \{Rybushkin M. S. A brief history of the city of Kazan. Kazan, 1849.\}

Рычков 1762 - Рычков П. И. Топография Оренбургская, то есть: областное описание Оренбургской губернии, сочиненное колледжским советников и императорской академией наук корреспондентом Петром Рычковым: в 2-х ч. СПб., 1762. \{Rychkov P. I. The Orenburg topography, that is: a regional description of the Orenburg province, composed by college advisers and the imperial academy of sciences, correspondent Peter Rychkov, in 2 parts. St. Petersburg, 1762.$\}$

Рычков 1896 - Рычков П. И. История Оренбургская по учреждении Оренбургской губернии. Оренбург, 1896. $\{$ Rychkov P. I. History of Orenburg on the establishment of the Orenburg province. Orenburg, 1896.\} 
Священная история 1862 - Священная история от сотворения мира до кончины Иосифа по книге Бытия, изложенная на народном татарском языке. Казань, 1862. \{Sacred history from the creation of the world to the death of Joseph according to the book of Genesis, set out in the folk Tatar language. Kazan, 1862.\}

Словарь 1876 - Первый опыт словаря народно-татарского языка по выговору крещенных татар Казанской губернии. Составитель Николай Остроумов. Казань, 1876. \{The first experience of the dictionary of the folk Tatar language on the reprimand of the baptized Tatars of the Kazan province. Compiled by Nikolay Ostroumov.\}.

Словарь 1880 - Словарь татарского языка. Казань, 1880. \{Tatar language dictionary. Kazan, 1880.\}

Соловьев 1851-1879 - Соловьев С. М. История России с древних времен: в 6 книгах. СПб., 1851-1879. \{Solovyev S. M. History of Russia from ancient times in 6 books. St. Petersburg, 1851-1879.\}

Требник 1881 - Требник на татарском языке. Казань, 1881. \{Trebnik in Tatar language. Kazan, 1881.\}

ТХC 2008 - Татар халык сөйләшләре. Беренче китап. (Говоры татарского народа. Первая книга). Казан, 2008. \{Tatar people subdialects. Second edition. Kazan, 2008.\}

ТЭС 1999 - Татарский энциклопедический словарь. Казань, 1999. \{Tatar encyclopedic dictionary. Kazan, 1999.\}

Учение 1897 - Чын ден княгясе. (Учение о православной вере). Казань, 1897. \{Studies on The Orthodox faith. Kazan, 1897.\}

ЧДК 1897 - Чын ден княгясе. (Учение о православной вере). Казань, 1897. \{Чын ден княгясе. Doctrine of the Orthodox faith. Kazan, 1897.\}

Чернышев 1971 - Чернышев E. Н. Селения Казанского ханства // Вопросы этногенеза тюркоязычных народов Среднего Поволжья. Вып. 1. Казань, 1971. \{Chernyshev E. N. Kazan Khanate Villages // Questions of ethnogenesis of the Turkic-speaking peoples of the Middle Volga region. Vol. 1. Kazan, 1971.\}

Шаймердинова 2016 - Шаймердинова Н. Г. Анализ системы консонантизма в казахских памятниках конца ХІХ — начала ХХ вв. // Урало-алтайские исследования. 2016, 4 (23). С. 128-137. \{Shaymerdinova N. G. Analysis of the system of consonants in Kazakh monuments of the late $19^{\text {th }}$ - early $20^{\text {th }}$ centuries // Ural-Altaic Studies. 2016, 4(23). P. $128-137$.

Wolgatatarische Dialektstudien 1988 - Wolgatatarische Dialektstudien. Textkritische Neuausgabe der Originalsammlung von G. Bálint 1875-76. Herausgegeben von Á. Berta. Oriental Studies 7. Budapest, 1988.

Concordance of the book of Jakov Emelyanov "Стихи на крещено-татарском языке”: http://lingvodoc.ispras.ru/ dictionary/3914/1/perspective/3914/2/publish.

Электронный атлас татарских народных говоров: http://atlas.antat.ru/atlas/maps.html?mapnom=2. 